\title{
4 | Mobilization through litigation: claiming health rights on asbestos issues in South Africa
}

\author{
NARDIA SIMPSON AND LINDA WALDMAN
}

Citizens seeking to claim their rights, demand redress for grievances or increase pressure for political change may, in many instances, turn to litigation to do so (see Felstiner et al. 1980; Hershkoff and Hollander 2000; Houtzager 2005). Indeed, civil rights movements have historically used the courts as a means to claim their rights as citizens. Recently, however, the legal landscape has been marked by the rise of transnational litigation against corporations and states, as citizens of developing countries have begun to use foreign courts, particularly in the United States and the United Kingdom, to redress wrongs that occurred in their home country. These class actions, undertaken by large numbers of citizens, rather than individuals, are generally underpinned by collective social activism in their home countries and thus operate in a unique transnational and legal context. Because of the focus on legal activism, these movements straddle global and national contexts in peculiar ways. They are integrated into - and draw upon - global social movements as stimulants for their activism while simultaneously the legal paradigms ground their actions in particular national contexts. This chapter examines one of the first examples of social mobilization and transnational litigation which was labelled as a legal success. In exploring the role of litigation and identity in transnational mobilization, it examines how mobilization - or the lack thereof - contributes to citizen empowerment in specific local contexts. Contrary to much of the literature which sees global mobilization networks as critical to citizen empowerment, and which has emphasized transnational civil society (Edelman 2001; Laclau and Mouffe 1985; Touraine 1988), this chapter argues that the effects of transnational litigation in conjunction with mobilization can be misinterpreted and uneven. Most critically, however, the chapter shows how processes of social mobilization and transnational litigation are reinterpreted according to local contexts and identities. Using the example of asbestos litigation and Griqua social identity, the chapter argues that the relationship between litigation and mobilization is more problematic than often assumed, and does not always result in citizen empowerment. As demonstrated in this 
chapter, even when the litigation is successful, some claimants interpret the case as a bitter defeat. We seek to explore why South Africans in two neighbouring towns experienced the case so differently. We do this by examining the construction of an international legal case in conjunction with the particular local sociocultural experiences and identities of the towns' residents.

In July 2003 a British company, Cape plc, which was formerly engaged in asbestos mining and milling operations, agreed to transfer $£ 10.5$ million to the Hendrik Afrika Trust, which was established to provide compensation for the 7,500-plus claimants in South Africa who suffer from asbestos-related diseases (ARDs). A further £10.5 million was to be paid into the fund over ten years. The creation of this trust was the culmination of an out-of-court settlement that occurred on 22 December 2001. Reaching the settlement had taken more than four years. However, after Cape defaulted from this payment, citing plummeting share values and financial instability, a final settlement of $£ 7.5$ million was paid and distributed among the claimants. In the small rural town of Prieska, in the Northern Cape, the settlement was part of a process that began in the 1980 s when a local group of activists commenced a campaign for improved access to asbestos compensation. (See L. Waldman 2007 for a detailed analysis of this legal campaign.) The settlement and Cape plc's payment are often considered to be a legal success story. For many people within South Africa, this story of international litigation, local mobilization, activist networks and asbestos pollution is, without doubt, a David and Goliath story in which poor, disempowered people took on a powerful, international company and won. As Ward argues, the litigation is also a legal breakthrough as it is the first example of a foreign direct liability case in which personal injury actions were brought by South Africans against parent companies of English multinationals in the English High Court (Ward 2002). Along with other product liability cases around the world (Jasanoff 1995; Newell 2001), this has come to be seen by some as a means of ensuring that corporations are held accountable and as a way to deliver compensation to injured workers.

Throughout the litigation, non-governmental organizations (NGOs), academics and lawyers assumed that, although small by British standards, this compensation would greatly benefit impoverished communities. In fact, the poverty of the affected communities was identified as a key argument for pursuing international litigation against toxic abuses in South Africa, coupled with the lack of legal expertise or financial aid and the powerful incentives not to address corporate irresponsibility in the 
claimants' home country (McCulloch 2002; Meeran 2003). As such, the settlement can be viewed as a significant victory. As demonstrated below, however, some claimants see this case as a bitter defeat. In attempting to explain the diverse interpretations of the same litigation and the resultant tensions, this chapter draws on the literature of social movements, political mobilization, ethnic identity and millenarian movements, relating these to everyday economic and cultural experiences in the Northern Cape. It examines the protest against asbestos pollution, and the subsequent legal claims and compensation, from the perspective of the people of Griquatown and Prieska. The chapter argues that neither assumptions about the instrumental benefits of litigation nor theories of social movements alone can adequately explain people's emic interpretations of international litigation and political mobilization. Rather, it is the linkages between these literatures, informed by an understanding of local ethnic identity, which provide a framework for understanding social behaviour and evaluating the 'success' of transnational litigation.

\section{Litigation and social movements}

The securing of compensation via the legal process can play an important role not only in a context where a large number of people have been injured, placing strain on public resources, but also in individual circumstances when health services are a minimal public right or nonbasic care is prohibitively expensive. In addition, access to legal services that can help secure financial resources to assist injured workers and their families has particular significance for poor populations where shocks in relation to the earning capacity of household members are very difficult to insure against.

Litigation is not, however, only about compensation and the satisfaction of material needs; litigation can also be considered beneficial if it generates publicity and mobilization around a particular cause. As Marcia Greenberger, former co-president of the National Women's Law Center (USA), explains, 'a concrete case could provide a way of highlighting the importance of a legal principle in the context of a real set of facts and actual people affected by the outcome. A case could serve to rally press and public attention to the legal principle at stake' (cited in Hershkoff and Hollander 2000: 96). Furthermore, the use of litigation can provide previously marginalized groups with a sense of legitimacy and protect members from public interference. As Joshi (2005) explains in relation to legal mobilization around the 'right to work' in India, a practical expectation of the litigation strategy was to cast a spotlight on the activities of 